\title{
The lessons of disaster
}

Received (in revised form): 30 September 2005

\section{Reas Kondraschow}

is the Senior Vice President and Managing Director of International Franchise Operations for Cendant Hotel Group International. There, he is responsible for development, marketing and support of the Ramada ${ }^{\circledR}$, Days $I n n^{\circledR}$, Howard Johnson ${ }^{\circledR}$, Super $8^{\circledR}$, and Wyndham ${ }^{\circledR}$, brands of the United states, Canada, Caribbean and Mexico. Mr. Kondraschow formerly was senior vice president and managing director of Ramada International Hotels \& Resorts in Bethesda, Md. From 1992 to 1998 , he was employed by Bass Plc. In roles of increasing responsibility, leading to senior vice president of franchise services, quality, architecture and construction. Mr. Kondraschow also worked for the Burger King Division of Pillsbury Company where he served in marketing, advertising and operations roles. When Pillsbury and its subsidiaries were acquired by Grand Metropoli$\tan$ in 1989, he was appointed vice president of franchising for the United States.

\begin{abstract}
In the past four years, natural and man-made disasters have had a tremendous effect on the tourism industry, including its retail and leisure components. By using the recent hurricanes in America and the tsunami in South Asia as examples, Reas Kondraschow contends that the economic impact of tourism is often overlooked, and that the various elements of the industry are inextricably linked. In light of his background in travel, and the far flung assets of his parent company, Cendant Corporation, Mr. Kondraschow urges each component of the tourism business to work together to assure the future good health of the industry.
\end{abstract}

\section{Keywords:}

disasters, economic impact, marketing, tourism

Journal of Retail and Leisure Property (2006) 5, 204-211. doi:10.1057/palgrave.rlp.5100011

Reas Kondraschow

Cendant Hotel Group International 1 Sylvan Way

Parsippany

N) 07054, USA

Tel: +19734965871

Fax: +19734965735

E-mail:

reas.kondraschow@cendant.com
Early in the year 2001, America's Federal Emergency Management Administration conducted a study ${ }^{1}$ to determine the three most likely disasters that might strike the United States in coming years.

First was a terrorist attack on the World Trade Center in New York City. The second was a hurricane-spawned flood of New Orleans. The third was a major earthquake along the San Andreas Fault in California.

Regrettably, the first two calamities came to pass in less than five years. Amid the terrible scenes of human suffering, recent hurricanes and the events of 9/11 uncovered America's vulnerability to both natural and man-made disasters. Considering that an earthquake generated the deadly tsunami that struck the Indian Ocean late in 2004, FEMA's study has been validated in a most painful way. 
Each of these disasters has revealed the need for improved communication among first responders and relief workers, as well as the governmental agencies charged with preventing or preparing for such emergencies before they happen.

But for those of us who specialise in tourism, including its retail and leisure components, these events illustrate two other tenets of our business that seem all too obvious now. First, the economic impact of tourism is never more apparent that when it has been taken away. Second, all the components of the tourism industry are inextricably linked to each other, no matter where they happen to serve travellers around the world.

The lesson yet to be learned, however, is that all of us must work together to assure the future good health of the tourism industry.

\section{A NEW WORLD}

The terrorist attacks of 11 September 2001 left an indelible mark on the tourism industry around the world. The attacks on the World Trade Center in New York, the Pentagon in Washington, DC and the airliner that crashed in Pennsylvania, was the subject of the 9/11 Commission Report. ${ }^{2}$ The report pointed out confusion among emergency workers at the World Trade Center, including communications systems that did not synch up with other agencies. The report also made an overwhelming case for better coordination between government agencies that might have helped thwart the attacks in the first place.

The same dynamic is now playing out in New Orleans and the Gulf Coast where recent hurricanes swept away coastal homes, businesses, hotels and casinos like so many sand castles.

What is worse, the likelihood that levees around New Orleans would fail in the face of a major hurricane was well-known to local, state and federal officials. The New Orleans Time-Picayune newspaper wrote a prescient series ${ }^{3}$ three years ago laying out just the kind of problems that would ensue if the city were flooded.

A predictably partisan political debate is now underway to lay blame for the disaster at the doorstep of city hall, the state house or the White House. Why were recommendations for improving the levee system ignored? Why were thousands of the city's poorest residents left behind during the city's voluntary evacuation? Why did it take so long to deliver food and water to those left behind in the Super Dome and the New Orleans Convention Center? Had the war in Iraq siphoned off too many National Guard troops who would have otherwise been mustered in advance of an approaching hurricane?

Whatever answers emerge in the months ahead, it is certain that this would not be the last natural or man-made disaster to strike the United States. In spite of the nation's latest cataclysmic events, the Red Cross estimates that nearly two-thirds of American families do not have disaster supply kits. ${ }^{4}$ The first order of business, obviously, is to help people affected by recent disasters. But in the long term, a renewed national and family focus on preparedness could be the best possible legacy of these US tragedies.

Of course, the disasters in North America pale in comparison to the enormous impact of typhoons, cyclones and earthquakes that plague Asia, 
Table I: Asian Tsunami death toll

\begin{tabular}{lc}
\hline Country & Deceased \\
\hline Indonesia & 232,732 \\
Sri Lanka & 30,974 \\
India & 16,389 \\
Thailand & 5,395 \\
East Africa & 394 \\
Maldives & 82 \\
Malaysia & 68 \\
Burma & 61 \\
\hline
\end{tabular}

Figures from International Federation of the Red Cross.

especially the December 26 tsunami that victimised millions of people living in coastal communities on the Indian Ocean. According to figures compiled by the International Federation of the Red Cross, ${ }^{5}$ the death toll was staggering (Table 1).

While it is obviously too late for these victims and their families, work has finally begun on a multinational tsunami warning system for South Asia that could have saved countless lives if it were in place in December of 2004.

The horror of the worst natural disaster of our time has been mitigated in part by the world's heartfelt response to the helpless victims of the tidal wave. Nearly every country on the globe has jumped in to assist. According to a report by journalist Fabio Scarpello, more than $\$ 1.8$ billion has been donated to help rebuild homes and communities that had been washed away, all from individual donors. 'Their governments, unable to ignore the popular momentum that saw concerts and benefits spring up like mushrooms in the autumn rain, also responded generously,' he wrote in the New Internationalist Magazine series, Waves that Woke the World. ${ }^{6}$ By early February, more than $\$ 7$ billion had been pledged in donations.

'Amid the devastation came the realisation that people of different nations can work together to alleviate suffering,' Scarpello concluded. 'Could something wonderful spring from this disaster: the realisation that cooperation and understanding between peoples can be forged?'

\section{TOURISM INDUSTRY COMES TOGETHER}

The tourism industry joined the world community in delivering immediate aid to tsunami victims. I was particularly impressed by the work of a small foundation in Germany, Luftfahrt ohne Grenzen (LOG), ${ }^{7}$ that filled the belly of an Air Lanka Airbus with donated tents and baby food within 48 hours of the tidal wave. LOG, the German iteration of Aviation sans Frontiere (Aviation Without Borders), was launched in 2003 with donations from the Conrad N. Hilton Foundation and the European Aeronautic Defence and Space Co. (EADS) - the maker of Airbus.

With non-governmental agencies not yet on the ground to administer disaster relief, LOG sent board members to accompany the cargo to ensure that it would not languish on the tarmac in Colombo. They hired a 
truck and drove north into rebel territory controlled by the Tamil Tigers who welcomed the much-needed relief supplies. LOG connected with the Catholic archbishop of Kandy in the ancient Sri Lankan capital who took responsibility for distributing the materials.

LOG also funded fabrication of 100 dories and nets - all made in Sri Lanka - to fisherman whose boats were lost during the tsunami. LOG shipped additional supplies to Colombo on Air Lanka, and together with EADS, sent a mobile operating room aboard a chartered Russian transport plane from Germany to another of the world's trouble spots, Bande Aceh.

There are thousands of other examples of aid generated by the retail and leisure components of the tourism industry. One of the most dynamic was created by the Victorian chapter of the Australian Federation of Travel Agents (AFTA). ${ }^{8}$ The group launched a unique plan to raise funds for tsunami relief, then provide low interest loans to travel industry colleagues whose businesses were destroyed or damaged in affected areas.

The programme, operated in partnership with Austcare, raises money from within the Australian travel industry, then provides funds to travel businesses in tsunami-hit regions for the purpose of infrastructure reconstruction.

'Millions of dollars have already been raised throughout Australia to provide general assistance to victims of the tsunami in Asia,' said AFTA Vice Chairman Mario Perrone. 'Our aim is more specific — to provide direct assistance to colleagues in our own industry whose businesses have been destroyed or seriously impaired by this catastrophe. Many of our travel industry colleagues in affected areas have either lost their incomes and assets, or suffered significant depreciation of their positions, and are not able to meet the minimum security requirements required by commercial lenders.'

All funds raised through the Victorian AFTA appeal will be maintained in an Austcare bank account that is subject to audit and the scrutiny of officers of the St. George Bank. As infrastructure is rebuilt, and businesses are restarted, funds will be repaid gradually then recirculated in new loans to other travel professionals who have also been affected by this disaster and are seeking to rebuild their businesses.

\section{BRINGING BACK TOURISTS}

The majority of travellers planning to visit Asia said that they would like more information about areas affected by the tsunami, mainly relating to health and sanitation, followed by reports on the clean-up and the impact the tsunami has had on infrastructure and tourist facilities.

These are some of the findings from the Post-Tsunami Global Travel Intentions Research ${ }^{9}$ conducted by Visa Asia Pacific for the World Tourism Organization (WTO) Emergency Task Force. The main findings were released at the Task Force's meeting at the International Tourism Exchange (ITB) in Berlin.

'Since the tsunami disaster, there has been a significant drop in international travel to affected tourist destinations such as Phuket in 
Thailand, Sri Lanka and the Maldives,' said Visa's Asia Pacific Executive Vice President James Murray. 'In spite of the significant success the various countries have had in restoring facilities and infrastructure, the tsunami severely damaged the livelihood of many local communities dependent on tourism revenues. Destinations in South and Southeast Asia are not only faced with the task of reconstruction, but also the formidable challenge of enhancing tourist confidence around the world.'

Murray stressed the urgent need for a better understanding of the attitudes of travellers from key markets, and of the barriers that may be keeping them away. Equipped with this information, national tourism organisations, policy makers, tourism operators and merchants in the tsunami-stricken countries will be better able to address the most salient issues and concerns among global travellers, restore tourist confidence, and stimulate travel back to their countries more effectively.

\section{TSUNAMI'S IMPACT ON TRAVEL VARIES BY SOURCE MARKET}

According to surveyed travellers who are planning to visit Asia, 65 per cent said the tsunami had no impact on their travel plans to the region as a whole. While 52 per cent felt the tsunami had not impacted their travel plans specifically to the affected areas, 30 per cent said the tsunami's aftermath is deterring them from visiting these destinations.

The tsunami's impact is most severe on Japanese and Korean travellers compared with all other visitors, dampening their travel intentions not only to tsunami-affected countries, but also to the rest of Asia. Forty-nine per cent of Japanese and 60 per cent of Korean travellers said that they are less likely to travel in the Asian region because of the tsunami. On the other hand, the tsunami has the least impact on the travel plans to affected countries among Canadian travellers (69 per cent claimed it had no impact), followed by the French ( 65 per cent), Germans ( 60 per cent) and Australians (60 per cent).

In some countries, the tsunami actually had a positive impact on travel to Asia. Around one-fifth of travellers said the tsunami has made it more likely for them to visit affected countries, especially those from China (20 percent), UK (19 per cent), Canada (18 per cent) and Sweden (18 per cent). This is a reflection of altruistic sentiments and a show of support for the local communities, especially among Canadian, British, Swedish and Australian travellers. They expressed strong belief that taking a holiday in the affected countries is an excellent way to help the communities and economies recover from the disaster. However, this is also tempered to some extent by feelings that they found it inappropriate to holiday while the local people are having a difficult time.

'The Visa research clearly shows that the tsunami's impact on travel to Asia varies considerably by source market,' Murray said. 'Travellers from some countries have higher levels of apprehension and resistance to visiting tsunami-affected countries, while others seem much more impervious and supportive. The tourism industry across Asia may need to adopt a varied approach in communicating and marketing to different source markets to address consumers' main concerns.' 


\section{HEALTH AND SANITATION ARE PRIMARY CONCERNS}

The majority of those planning to travel to Asia said that they would like more information about the affected areas, especially regarding health and sanitation. Progress on the clean-up and the impact of tsunami on infrastructure and tourist facilities also ranked high among prospective visitors.

Most of the barriers to travel seem to be based on inadequate perceptions about the infrastructural readiness and safety of the destinations. These are issues that can be addressed with a targeted communications strategy that highlights the recovery of the tourism destinations. Increased awareness of the health of the Asian tourism industry, in terms of infrastructure, service and ambience, is critical to speed up the recovery and minimise further risks of slowdown.

\section{ADDED SECURITY PRECAUTIONS}

In light of recent disasters, the hotel industry is taking steps to increase the security and safety of its guests around the world. For example:

- Hotels are conducting emergency response training, and are drilling their staffs to quickly and efficiently evacuate the property.

- Steps are being taken to improve communication among hotels, and their link to their corporate headquarters.

- Guests are being educated on emergency procedures, and additional information is being placed in guest rooms.

- Insurers are conducting more intensive risk assessment, leading to changes to the physical plant which can better protect hotel guests from fire, flood, earthquake or other emergencies.

- Hotels are being equipped with life-safety devices, such as automatic defibrillators, following the lead of the airline industry.

- Duplicate sets of guest lists are being kept to assist emergency workers in identifying victims should computer systems fail.

\section{GULF COAST RECOVERY}

Five hours after Hurricane Katrina made landfall at New Orleans on August 29, the levees protecting the low-lying areas of the city failed. The damage from the flooding far exceeded the damage from wind and rain generated by the Category 4 storm. The levee system failed again when Category 3 Hurricane Rita struck the Gulf Coast three weeks later.

It is a bittersweet irony that the most-visited area of New Orleans the quaint French Quarter - survived the recent storms virtually intact. French settlers founded the city on a big bend in the Mississippi River where centuries of silt deposits had created the highest point in the area. Levees were built over the decades to enable development of the rest of the city. But until the infrastructure is restored and local residents move back to new or restored homes, the hotels, restaurants and shops of New Orleans are likely to remain empty of tourists. 


\section{PATRIOTIC APPEAL}

New Orleans civic leaders need to make a patriotic appeal to lure domestic tourists back to the city, and show international travellers that New Orleans is 'back in business.'

In the aftermath of 9/11, even as victims were still being pulled from the wreckage of the World Trade Center, city, state and federal organisations joined private companies in an effort to generate tourism to New York. After initial fear of another terrorist attack subsided, domestic and international markets responded very well to an appeal to travel to New York. The site of the disaster, known as 'Ground Zero', has become one of Manhattan's most moving cultural attractions for domestic and international travellers alike.

The residual effects of the tragedy, however, were felt around the world. Fear of terrorism, the war in Afghanistan and Iraq, and the SARS outbreak combined to create a travel slowdown that sent the world economy into a steep recession.

On the eve of 2004, World Travel and Tourism Council ${ }^{10}$ President Jean-Claude Baumgarten said the industry was finally poised for a robust recovery in the year ahead. 'I am cautiously optimistic that we have weathered the perfect storm of terrorism, war and health concerns that created a disproportionate toll of concern and impact on our consumers, the industry and our economy,' he said. 'We've learned a number of lessons these past three years about tourism's sensitivity to external events. Perhaps one of the biggest lessons is that the economic impact of the industry goes well beyond the traditional notion of airlines, hotels, car rental agencies and tour operators. It reaches well into the fabric of our economies.'

Baumgarten added that, when the front line of travel and tourism is affected by a decrease in demand, the entire economy suffers. 'Although the tourism industry can and does do a great deal to help alleviate the concerns of our customers and get them moving again, government officials must step in and become partners with the industry to strengthen its position and resolve.'

Government flood insurance and low-cost loan programmes will help hurricane victims recover on the US Gulf Coast, and many of the displaced residents will be hired during reconstruction. Retail, leisure and travel companies should work together with governmental agencies to help communicate with prospective travellers around the world.

Cendant embarked on a special fundraising campaign on behalf of the American Red Cross Hurricane 2005 Relief Fund through which the Cendant Charity Foundation matched employee donations up to an aggregate of $\$ 500,000$. Cendant's Car Rental Group, Hotel Group and Timeshare Resort Group worked with FEMA, the Department of Homeland Security and the American Red Cross to provide assistance during the recovery, including access to hotels and rental vehicles for emergency response personnel moving into the area to coordinate relief efforts.

Cendant also worked with its strategic partners, as well as its many travel and real estate companies, to help rebuild tourism in South Asia, Southeast Asia and the Gulf Coast of the United States. It is in everyone's 
mutual best interest to work together to get the word out when these regions are finally back in business, and ready, willing and able to host visitors from around the world.

\section{References}

1. Krugman, P. (2005) A Can't-Do Government. New York Times. 2 September.

2. 9/11 Commission Report (2004) US Government Printing Office. 22 July.

3. New Orleans Times-Picayune (2002) Special Report: Washing Away. 23-27 June, five-part series.

4. Fairview Heights Journal (2003) Red Cross Offers Disaster Kits. 19 October.

5. New International Magazine (2004) Waves that Woke the World. April 2004. Figures compiled by International Federation of the Red Cross as of the end of February 2004. Figures for Indonesia and India include those missing, presumed dead.

6. Ibid.

7. Franke, F (2005) Damit Hilfe Flügel bekommt: Luftfahrt ohne Grenzen hilft Flutopfer in Indonesien. 2 February.

8. eTravel Blackboard (2005), 6 February.

9. AC Nielsen Research Study (2005), 'Post-tsunami global travel intentions research, 10 March.

10. World Travel Tourism Council (2004), 'Travel \& tourism forecast for 174 countries of the world. 10 March 2004 